\title{
Burkholderia bannensis sp. nov., an acid- neutralizing bacterium isolated from torpedo grass (Panicum repens) growing in highly acidic swamps
}

\author{
Correspondence \\ Tomoko Aizawa \\ t-aizawa@brs.nihon-u.ac.jp
}

\author{
Tomoko Aizawa, ${ }^{1}$ Pisoot Vijarnsorn, ${ }^{2}$ Mutsuyasu Nakajima ${ }^{1}$ \\ and Michio Sunairi ${ }^{1}$
}
${ }^{1}$ Department of Applied Biological Sciences, College of Bioresource Sciences, Nihon University, 1866 Kameino, Fujisawa, Kanagawa 252-0880, Japan
${ }^{2}$ Banna Experimental Station for Royal Acid Sulfate Soil Improvement Project under Royal Initiatives, Banna, Nakhon Nayok 26110, Thailand

Two strains of acid-neutralizing bacteria, $E 25^{\top}$ and $\mathrm{E} 21$, were isolated from torpedo grass (Panicum repens) growing in highly acidic swamps ( $\mathrm{pH} \mathrm{2-4)} \mathrm{in} \mathrm{actual} \mathrm{acid} \mathrm{sulfate} \mathrm{soil} \mathrm{areas} \mathrm{of}$ Thailand. Cells of the strains were Gram-negative, aerobic, non-spore-forming rods, 0.6-0.8 $\mu \mathrm{m}$ wide and 1.6-2.1 $\mu \mathrm{m}$ long. The strains showed good growth at $\mathrm{pH} 4.0-8.0$ and $17-37{ }^{\circ} \mathrm{C}$. The

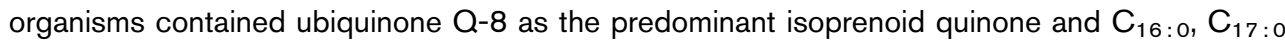
cyclo and $\mathrm{C}_{18: 1} \omega 7 \mathrm{c}$ as the major fatty acids. Their fatty acid profiles were similar to those reported for other Burkholderia species. The DNA G+C content of the strains was $65 \mathrm{~mol} \%$. On the basis of $16 \mathrm{~S}$ rRNA gene sequence similarity, the strains were shown to belong to the genus Burkholderia. Although the calculated 16S rRNA gene sequence similarity of E25 ${ }^{\top}$ to strain E21 and the type strains of Burkholderia unamae, B. tropica, B. sacchari, B. nodosa and $B$. mimosarum was $100,98.7,98.6,97.6,97.4$ and $97.3 \%$, respectively, strains $E 25^{\top}$ and E21 formed a group that was distinct in the phylogenetic tree; the DNA-DNA relatedness of $E 25^{\top}$ to E21 and B. unamae CIP $107921^{\top}$, B. tropica LMG $22274^{\top}$, B. sacchari LMG $19450^{\top}$, B. nodosa LMG $23741^{\top}$ and $B$. mimosarum LMG $23256^{\top}$ was $90,42,42,42,45$ and $35 \%$, respectively. The results of physiological and biochemical tests including whole-cell protein pattern analysis allowed phenotypic differentiation of these strains from previously described Burkholderia species. Therefore, strains $E 25^{\top}$ and E21 represent a novel species, for which the name Burkholderia bannensis sp. nov. is proposed. The type strain is $\mathrm{E}^{2} 5^{\top}\left(=\mathrm{NBRC} 103871^{\top}=\mathrm{BCC}\right.$ $36998^{\top}$ ).
Yabuuchi et al. (1992) created the genus Burkholderia by the transfer of seven species from Pseudomonas, with Burkholderia cepacia as the type species. At the time of writing, the genus Burkholderia comprises more than 60 species, occupying a wide range of ecological niches and showing a variety of metabolic activities (Coenye \& Vandamme, 2003). During the course of a study to characterize waterweeds adapted to highly acidic aquatic environments ( $\mathrm{pH} 2-4)$ in actual acid sulfate soils (AASS) in South-East Asia (Aizawa et al., 2008; Sasaki et al., 2008), we have isolated a number of bacteria associated with the waterweeds and reported several novel bacterial species

Abbreviation: AASS, actual acid sulfate soil.

The GenBank/EMBL/DDBJ accession numbers for the 16S rRNA gene sequences of strains $E 25^{\top}$ and $E 21$ are AB561874 and AB561875.

Three supplementary figures and three supplementary tables are available with the online version of this paper.
(Aizawa et al., 2007, 2010b, c; Kimoto et al., 2010). In the present study, we characterized two acid-neutralizing bacteria, $\mathrm{E} 25^{\mathrm{T}}$ and $\mathrm{E} 21$, isolated from torpedo grass (Panicum repens; see Supplementary Fig. S1, available in IJSEM Online) growing in a highly acidic swamp ( $\mathrm{pH} 2.9)$ at Banna Experimental Station in Nakhon Nayok Province, Thailand. By a polyphasic approach, including 16S rRNA gene sequence analysis, DNA-DNA hybridization, wholecell protein analysis, fatty acid methyl ester analysis and phenotypic and biochemical characterization, the strains were shown to be affiliated with the genus Burkholderia. The data obtained suggest that the strains represent a novel species of the genus Burkholderia.

Each $P$. repens plant was divided into leaves, aerial stems, underwater stems and roots. After gentle washing in excess saline for $1 \mathrm{~min}$ to remove loosely attached soil, each part was transferred to fresh saline and shaken vigorously for $15 \mathrm{~min}$; this procedure was repeated three times. The 
extracts were combined (to give sample LBM). The LBM sample was transferred to fresh saline and shaken vigorously for $18 \mathrm{~h}$ (to give sample TBM). A number of bacteria were isolated from samples LBM and TBM by using one-tenth-strength tryptic soy (1/10 TS) agar plates [3.0 g tryptic soy broth $\mathrm{l}^{-1}$ solidified with $15.0 \mathrm{~g}$ agar $\mathrm{l}^{-1}$ (both from Difco)] at $\mathrm{pH}$ 4.0. For preparation of these acidic plates, double-strength medium and $3 \%$ agar solution were autoclaved separately to prevent hydrolysis of the agar and then mixed. Among the isolates, acidneutralizing bacteria were selected on the basis of neutralization of $1 / 10$ TS liquid medium ( $\mathrm{pH} 4.0$ ), determined by measuring the $\mathrm{pH}$ of the culture supernatants after 3 days of cultivation.

Strains E25 ${ }^{\mathrm{T}}$ and E21 were isolated from TBM samples prepared from a root and an aerial stem, respectively, from the same plant collected in Thailand. Both strains formed round, smooth, convex, pale-yellow colonies with entire margins on 1/10 TS agar plates ( $\mathrm{pH} 4.0)$. Each showed good growth on these plates at $17-37{ }^{\circ} \mathrm{C}$, with optimum growth at $28-32{ }^{\circ} \mathrm{C}$, but did not grow at 5 or $42{ }^{\circ} \mathrm{C}$. Strains $\mathrm{E} 25^{\mathrm{T}}$ and $\mathrm{E} 21$ showed good growth at $\mathrm{pH} 3-8$, with optimum growth at $\mathrm{pH} 4-7$ and no or little growth below $\mathrm{pH} 2$ or above $\mathrm{pH} 9$ when cultured at $30{ }^{\circ} \mathrm{C}$ for 5 days. The strains grew as well on TS plates ( $\mathrm{pH} 4.0)$ as on $1 / 10$ TS agar plates ( $\mathrm{pH} 4.0)$. Growth under anaerobic conditions was determined after 5 days of incubation at $30{ }^{\circ} \mathrm{C}$ in an AnaeroPack (Mitsubishi Gas Chemical Co., Ltd). The strains grew well on 1/10 TS plates $(\mathrm{pH} \mathrm{4.0)}$ under aerobic conditions but not under anaerobic conditions, indicating that they are aerobes. Cells grown on 1/10 TS agar plates ( $\mathrm{pH}$ 4.0) were Gram-negative (Ryu, 1938), non-endospore-forming and non-motile. Their morphology was observed by scanning electron microscopy, as described previously (Aizawa et al., 2010b). The cells were irregular rods, $0.6-0.8 \mu \mathrm{m}$ wide and 1.6-2.1 $\mu \mathrm{m}$ long, after growth on $1 / 10$ TS agar plates ( $\mathrm{pH} 4.0$ ) at $28{ }^{\circ} \mathrm{C}$ for 3 days.

The 16S rRNA genes of the strains were amplified by PCR using universal primers (Tamura \& Hatano, 2001), and nearly complete 16S rRNA gene nucleotide sequences were determined. The NCBI BLAST software tool (http://www. ncbi.nlm.nih.gov/blast/Blast.cgi) and the EzTaxon software (Chun et al., 2007) were applied to compare the determined 16S rRNA gene sequences with those of type strains. These sequences showed high similarity to species within the genus Burkholderia. The 16S rRNA gene sequence similarities of strain $\mathrm{E} 25^{\mathrm{T}}$ to strain E21, Burkholderia unamae $\mathrm{MTl}-641^{\mathrm{T}}$, B. tropica $\mathrm{Ppe}^{\mathrm{T}}, \quad$ B. sacchari LMG $19450^{\mathrm{T}}$, B. nodosa $\mathrm{Br} 3437^{\mathrm{T}}$ and B. mimosarum PAS44 ${ }^{\mathrm{T}}$ were 100, 98.7, 98.6, 97.6, 97.4 and $97.3 \%$, respectively. Phylogenetic relationships of $\mathrm{E} 25^{\mathrm{T}}$ and E21 with closely related species were determined by using MEGA version 4 (Tamura et al., 2007) and the PHYLIP 3.65 package (Felsenstein, 2005) after performing multiple alignments of the data with CLUSTAL_x (Thompson et al., 1997). Evolutionary distances were computed as described previously (Jukes \& Cantor, 1969). Phylogenetic trees were reconstructed by using the maximum-parsimony (Kluge \& Farris, 1969), maximum-likelihood (Felsenstein, 1981), minimum-evolution (Rzhetsky \& Nei, 1992) and neighbour-joining (Saitou \& Nei, 1987) methods. The reliabilities of these tree topologies were evaluated by bootstrap analysis with 1000 replicates (Felsenstein, 1985). Phylogenetic trees reconstructed by these four methods were topologically similar and showed that strains $\mathrm{E} 25^{\mathrm{T}}$ and E21 belonged to the genus Burkholderia, within which the strains formed a cluster with strains of some Burkholderia species isolated from plants and soil: Burkholderia tuberum (Vandamme et al., 2002), B. mimosarum (Chen et al., 2006) and B. nodosa (Chen et al., 2007), isolated from leguminous Mimosa species, Burkholderia silvatlantica (Perin et al., 2006), B. unamae (Caballero-Mellado et al., 2004) and B. tropica (Reis et al., 2004), isolated from maize and sugar cane, Burkholderia heleia (Aizawa et al., 2010b) and B. acidipaludis (Aizawa et al., 2010c), from Chinese water chestnut, Burkholderia sacchari (Brämer et al., 2001), isolated from soil of a sugar cane plantation, and Burkholderia kururiensis M130 (Caballero-Mellado et al., 2007), isolated from the root of a rice plant growing in Brazil (Baldani et al., 1997; Weber et al., 1999), as well as Burkholderia ferrariae (Valverde et al., 2006), isolated from iron ore. The phylogenetic tree reconstructed by using the neighbour-joining method is shown in Fig. 1. Although the strains showed a high degree of $16 \mathrm{~S}$ rRNA gene sequence similarity to established species of the genus, they formed a separate line of descent in the phylogenetic cluster of the genus (Fig. 1). Stackebrandt \& Goebel (1994) pointed out that a high degree of $16 \mathrm{~S}$ rRNA gene sequence similarity (97\% or higher) is of limited value for differentiating species, and that DNA-DNA hybridization studies must be performed to determine species affiliation under these

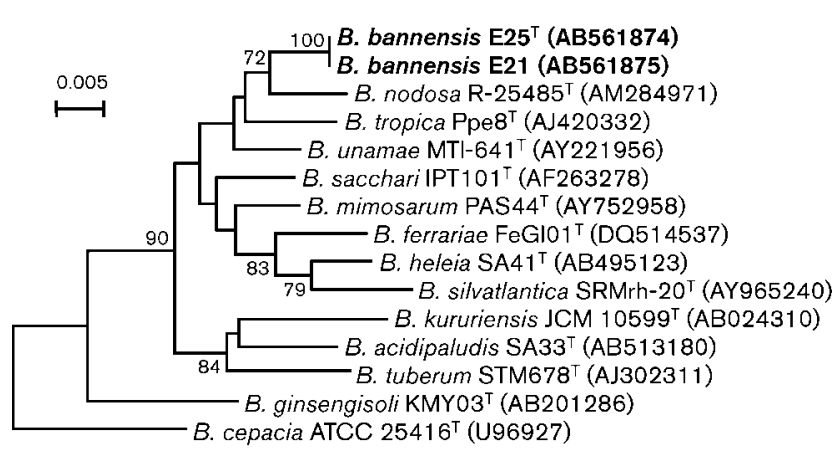

Fig. 1. Neighbour-joining tree based on nearly complete $16 \mathrm{~S}$ rRNA gene sequences (positions 150-1418 of the Escherichia coli $16 \mathrm{~S}$ rRNA gene), showing the positions of strains $E 25^{\top}$ and E21 among their phylogenetic neighbours. Numbers at branch nodes are percentages based on 1000 bootstrap resamplings; only values over $70 \%$ are given. The sequences of Burkholderia cepacia ATCC $25416^{\top}$ and Burkholderia ginsengisoli $\mathrm{KMYO3}^{\top}$ were used as the outgroup. Bar, 0.005 substitutions per nucleotide position. 
circumstances. Therefore, we performed DNA-DNA hybridization on these strains and their neighbours on the phylogenetic tree by using the microplate hybridization method (Ezaki et al., 1988, 1989) as described by Tamura et al. (1999). Hybridization was performed at $51{ }^{\circ} \mathrm{C}$ for $3 \mathrm{~h}$ using a hybridization solution containing $50 \%$ deionized formamide, $2 \times$ SSC $(1 \times$ SSC is $0.15 \mathrm{M} \mathrm{NaCl}, 0.015 \mathrm{M}$ trisodium citrate, $\mathrm{pH} 7.0), 5 \times$ Denhardt's solution $(1 \times$ Denhardt's solution is $0.02 \%$ BSA, $0.02 \%$ polyvinylpyrrolidone and $0.02 \%$ Ficoll 400$), 0.1 \mathrm{mg}$ heat-denatured, sonicated salmon testes DNA ml ${ }^{-1}$ and $2.5 \%$ dextran sulfate. The DNA-DNA relatedness of strain $\mathrm{E} 25^{\mathrm{T}}$ to E21 was $90 \%$, which is higher than the recommended threshold value $(70 \%)$ for the delineation of genomic species (Wayne et al., 1987). Strain $\mathrm{E} 25^{\mathrm{T}}$ exhibited relatively low levels of DNA-DNA relatedness with respect to $B$. nodosa LMG $23741^{\mathrm{T}}(45 \%)$, B. unamae CIP $107921^{\mathrm{T}}$ (42\%), B. tropica LMG $22274^{\mathrm{T}}(42 \%)$, B. sacchari LMG $19450^{\mathrm{T}}(42 \%)$ and B. mimosarum LMG $23256^{\mathrm{T}}(35 \%)$, indicating that strain $\mathrm{E} 25^{\mathrm{T}}$ was not related to them at the species level. These data suggest that strains E25 ${ }^{\mathrm{T}}$ and E21 represent a novel species of the genus Burkholderia.

Strains $\mathrm{E} 25^{\mathrm{T}}$ and E21 could also be distinguished from closely related species of Burkholderia in the phylogenetic trees (Supplementary Fig. S2) on the basis of physiological characteristics (Supplementary Table S1). All physiological and biochemical experiments were done at least in triplicate using not only strains E25 ${ }^{\mathrm{T}}$ and E21 but also the type strains of phylogenetically closely related Burkholderia species, B. unamae CIP $107921^{\mathrm{T}}$, B. tropica LMG $22274^{\mathrm{T}}$, B. sacchari LMG $19450^{\mathrm{T}}$, B. nodosa LMG $23741^{\mathrm{T}}$ and B. mimosarum LMG $23256^{\mathrm{T}}$. Strains $\mathrm{E} 25^{\mathrm{T}}$ and E21 did not show positive results in acetylene reduction experiments (Burris, 1972) using Winogradsky's nitrogenfree mineral soft gel medium containing $1 \%$ mannitol (Hashidoko et al., 2002), whereas closely related type strains were positive, with the exception of $B$. acidipaludis SA33 $3^{\mathrm{T}}$, B. sacchari LMG $19450^{\mathrm{T}}$, B. kururiensis JCM $10599^{\mathrm{T}}$, B. tuberum LMG $21444^{\mathrm{T}}$, B. silvatlantica LMG $23149^{\mathrm{T}}$, B. heleia SA $41^{\mathrm{T}}$ and B. ferrariae LMG $23612^{\mathrm{T}}$. These data showed good agreement with results obtained by ${ }^{15} \mathrm{~N}_{2}$ incorporation assays (Martinez-Aguilar et al., 2008). The nifH PCR assay (Caballero-Mellado et al., 2007) was performed in this study for strains E25 ${ }^{\mathrm{T}}$ and E21 and also the type strains of phylogenetically closely related Burkholderia species. Interestingly, strains $\mathrm{E} 25^{\mathrm{T}}$ and $\mathrm{E} 21$, as well as $B$. acidipaludis SA $33^{\mathrm{T}}$ and $B$. ferrariae LMG $23612^{\mathrm{T}}$, gave positive results, whereas $B$. sacchari $\mathrm{LMG} 19450^{\mathrm{T}}$ gave a negative result; the results for $B$. sacchari LMG $19450^{\mathrm{T}}$ and $B$. ferrariae LMG $23612^{\mathrm{T}}$ were in accordance with a previous report (Caballero-Mellado et al., 2007). Further study might be necessary to determine the diazotrophy of these nif $H$ positive strains. Strains E25 ${ }^{\mathrm{T}}$ and E21 could grow in the presence of $1 \mathrm{mM} \mathrm{AlCl}$ in $0.1 \%$ BactoTryptone (Difco) adjusted to $\mathrm{pH} 3.5$ with sulfuric acid.

Standard physiological tests were carried out according to methods described previously (Smibert \& Krieg, 1994).
Acid production from carbon sources, enzyme activities and resistance to antibiotics were assessed by using the API $50 \mathrm{CH}$ system, API ZYM and API 20 E systems and ATB VET system (bioMérieux), respectively, according to the manufacturers' instructions. The utilization of various substrates as sole carbon sources was tested by using Biolog GN2 Microplates in accordance with the manufacturer's instructions. Physiological characteristics that differ between the novel strains and closely related species are summarized in Supplementary Table S1, and physiological diversity within the species is shown in Supplementary Table S2. The DNA G +C content was determined by the method described by Tamaoka \& Komagata (1984). The DNA G $+C$ content of strains E25 ${ }^{\mathrm{T}}$ and E21 was $65 \mathrm{~mol} \%$. Cellular fatty acids of the two strains and reference strains were saponified, methylated and extracted as described by Tamura et al. (1994). Fatty acid methyl esters were then analysed by using a Shimadzu model GCMS-QP5050 GC/ MS equipped with an SPB-1 column (Supelco). The major fatty acids of both strains grown on 1/10 TS agar plates containing $1 \%$ glucose $\left(\mathrm{pH} \mathrm{5.0)}\right.$ ) at $28{ }^{\circ} \mathrm{C}$ for 3 days were $\mathrm{C}_{16: 0}, \mathrm{C}_{17: 0}$ cyclo and $\mathrm{C}_{18: 1} \omega 07 c$ (Supplementary Table S2); similar patterns were obtained from cells of the type strains of closely related species. Isoprenoid quinones were prepared as described previously (Tamura et al., 1994) and analysed by using a Quattro premier MS coupled to an Acuity UPLC (UPLC/MS/MS; Waters) as described by Aizawa et al. (2010a). The major isoprenoid quinone of the strains was Q-8, as in the case of other species of the genus Burkholderia (Yamada et al., 1982; Zhang et al., 2000; Yang et al., 2006; Valverde et al., 2006; Aizawa et al., 2010b, c).

Whole-cell protein extracts were prepared from strains $\mathrm{E} 25^{\mathrm{T}}$ and E21 and the type strains of several related species and analysed by SDS-PAGE, as described previously (Pot et al., 1994); the results are shown in Supplementary Fig. S3. The newly isolated strains showed a clearly different protein profile from related species of Burkholderia. Since it is well known that bacteria with identical or very similar protein patterns possess high genome similarity (Vandamme et al., 1996), these SDS-PAGE results also support the notion that strains E25 ${ }^{\mathrm{T}}$ and E21 represent a novel acid-neutralizing Burkholderia species.

Therefore, based on the physiological, biochemical, chemotaxonomic and molecular genetic results described above, strains $\mathrm{E} 25^{\mathrm{T}}$ and $\mathrm{E} 21$ represent a novel species of the genus Burkholderia, for which the name Burkholderia bannensis sp. nov. is proposed.

\section{Description of Burkholderia bannensis sp. nov.}

Burkholderia bannensis (ban.nen'sis. N.L. fem. adj. bannensis pertaining to the Banna region of Nakhon Nayok Province, Thailand, where the first strains were isolated).

Cells are Gram-negative, strictly aerobic, non-spore-forming, non-motile rods $(0.6-0.8 \times 1.6-2.1 \mu \mathrm{m})$. Colonies are smooth, round, convex and pale yellow with entire margins after 3 days of cultivation at $32{ }^{\circ} \mathrm{C}$ on $1 / 10$ TS agar plates 
( $\mathrm{pH} 4.0$ ). Growth occurs at $17-37{ }^{\circ} \mathrm{C}$, with optimum

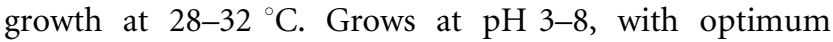
growth at $\mathrm{pH} 4-6$. Positive for hydrolysis of Tweens 20, 40, 60 and 80. Positive for oxidase, catalase, acid and alkaline phosphatases, esterase (C4), esterase lipase (C8), leucine arylamidase, naphthol-AS-BI-phosphohydrolase and reduction of nitrate to nitrite, but negative for hydrolysis of DNA and gelatin, lipase (C14), valine arylamidase, cystine arylamidase, trypsin, $\alpha$-chymotrypsin, $\alpha$-galactosidase, $\beta$ galactosidase, $\beta$-glucuronidase, $\alpha$-glucosidase, $\beta$-glucosidase, $N$-acetyl- $\beta$-glucosaminidase, $\alpha$-mannosidase, $\alpha$-fucosidase, proteinase, urease, arginine dihydrolase, indole production and reduction of nitrate to $\mathrm{N}_{2}$ (API ZYM, API 20E and API 20NE). Positive for acid production from glycerol, D- and Larabinose, D-ribose, D-xylose, D-adonitol, D-galactose, Dglucose, D-fructose, D-mannose, L-rhamnose, D-mannitol, D-sorbitol, arbutin, aesculin, cellobiose, maltose, lactose, melibiose, trehalose, gentiobiose, D-lyxose, D- and L-fucose and D-arabitol; negative for acid production from methyl $\alpha$ D-mannopyranoside, methyl $\alpha$-D-glucopyranoside, sucrose, inulin, melezitose, raffinose, starch, glycogen and turanose (API 50CH). Positive for utilization of Tweens 40 and 80, Nacetyl-D-glucosamine, adonitol, L-arabinose, D-arabitol, Dfructose, L-fucose, D-galactose, gentiobiose, $\alpha$-D-glucose, lactulose, D-mannitol, D-mannose, inositol, L-rhamnose, trehalose, pyruvic acid methyl ester, succinic acid monomethyl ester, cis-aconitic acid, citric acid, D-galacturonic acid, D-gluconic acid, D-glucosaminic acid, D-glucuronic acid, $\beta$-hydroxybutyric acid, $\alpha$-ketoglutaric acid, D-saccharic acid, succinic acid, succinamic acid, glucuronamide, Dalanine, L-alanyl glycine, L-aspartic acid, glycyl L-glutamic acid, L-histidine, hydroxy-L-proline, L-phenylalanine, Lserine, L-threonine, $\gamma$-aminobutyric acid, urocanic acid, thymidine, glycerol, DL- $\alpha$-glycerol phosphate and D-glucose 6-phosphate as sole carbon sources; negative for utilization of $\alpha$-cyclodextrin, glycogen, lactose, melibiose, methyl $\beta$-Dglucoside, D-psicose, raffinose, xylitol, $\alpha$-hydroxybutyric acid, itaconic acid, $\alpha$-ketobutyric acid, putrescine and 2,3butanediol (Biolog GN2). Resistant to $\left(\mu \mathrm{g} \mathrm{ml}^{-1}\right.$ ) penicillin (0.25), amoxicillin (4), amoxicillin/clavulanic acid (4/2), oxacillin (2), cephalothin (8), cefoperazone (4), erythromycin (1), lincomycin (2), pristinamycin (2), tylosin (2), colistin (4), sulfamethizole (100), nitrofurantoin (25), fusidic acid (2) and metronidazole (4); sensitive to ( $\mu \mathrm{g}$ $\mathrm{ml}^{-1}$ ) streptomycin (8), spectinomycin (64), kanamycin (8), gentamicin (4), apramycin (16), tetracycline (4), doxycycline (4), co-trimoxazole (2/38), flumequin (4), oxolinic acid (2), enrofloxacin (0.5) and rifampicin (4) (ATB VET). The major isoprenoid quinone is Q-8. The predominant cellular fatty acids are $\mathrm{C}_{16: 0}, \mathrm{C}_{18: 1} \omega 7 \mathrm{c}$ and $\mathrm{C}_{17: 0}$ cyclo. The DNA $\mathrm{G}+\mathrm{C}$ content of the two known strains is $65 \mathrm{~mol} \%$.

The type strain, E25 ${ }^{\mathrm{T}}\left(=\mathrm{NBRC} 103871^{\mathrm{T}}=\mathrm{BCC} 36998^{\mathrm{T}}\right)$, and a second strain, E21, were isolated from a root and an aerial stem, respectively, of Panicum repens, an aquatic plant growing luxuriantly in a highly acidic swamp (pH 2.9) in an AASS area in Thailand.

\section{Acknowledgements}

We are most grateful to S. Sasaki for giving us the opportunity to conduct this research. We also thank H. Uchiyama for identification of $P$. repens, D. J. Kang for help in collecting the samples and M. Ohkuma and S. Noda for advice on the acetylene reduction assay. We acknowledge T. Asai, M. Shimizu, K. Kimoto and various other members of our laboratories for their technical assistance and encouragement. We acknowledge P. Rattanawaree at the BCC and K. Suzuki, Y. Nakagawa and Y. Muramatsu at the NBRC for deposit of the isolates and K. Ueda at the Life Science Center for use of instrument facilities, as well as $\mathrm{M}$. Hyoudou-Nakamura, N. Murayama-Akimoto, T. Fujioka and N. Sekino at the Integrated Research Institute for their technical assistance. This study was partly supported by a grant from the Institute for Fermentation (IFO; Osaka, Japan) and the JST-NSFC Joint Research Program and by grants-in-aid for scientific research from the Japan Society for Promotion of Science (nos 21780300 and 23580462). T.A. was supported by funding from the 'High-Tech Research Center Projects' of the Ministry of Education, Culture, Sports, Science, and Technology of Japan.

\section{References}

Aizawa, T., Nguyen, B. V., Kimoto, K., Iwabuchi, N., Sumida, H., Hasegawa, I., Sasaki, S., Tamura, T., Kudo, T. \& other authors (2007). Curtobacterium ammoniigenes sp. nov., an ammoniaproducing bacterium isolated from plants inhabiting acidic swamps in actual acid sulfate soil areas of Vietnam. Int J Syst Evol Microbiol 57, 1447-1452.

Aizawa, T., Nguyen, B. V., Vijarnsorn, P., Kimoto, K., Sasaki, S., Nakajima, M. \& Sunairi, M. (2008). Application of symbiotic bacteria isolated from plants adapted to actual acid sulfate soil. In Development of New Bioremediation Systems of Acid Sulfate Soil for Agriculture and Forestry, pp. 57-62. Edited by S. Sasaki, R. Ishii, I. Hasegawa, T. Tokuyama, K. Hanzawa, H. Sumida, S. Ueda, A. Noguchi, R. Matsumoto \& other authors. Kyoto: Shoukadoh.

Aizawa, T., Urai, M., Iwabuchi, N., Nakajima, M. \& Sunairi, M. (2010a). Bacillus trypoxylicola sp. nov., xylanase-producing alkaliphilic bacteria isolated from the guts of Japanese horned beetle larvae (Trypoxylus dichotomus septentrionalis). Int J Syst Evol Microbiol 60, 61-66.

Aizawa, T., Nguyen, B. V., Nakajima, M. \& Sunairi, M. (2010b). Burkholderia heleia sp. nov., a nitrogen-fixing bacterium isolated from an aquatic plant, Eleocharis dulcis, that grows in highly acidic swamps in actual acid sulfate soil areas of Vietnam. Int J Syst Evol Microbiol 60, 1152-1157.

Aizawa, T., Nguyen, B. V., Vijarnsorn, P., Nakajima, M. \& Sunairi, M. (2010c). Burkholderia acidipaludis sp. nov., aluminium-tolerant bacteria isolated from Chinese water chestnut (Eleocharis dulcis) growing in highly acidic swamps in South-East Asia. Int J Syst Evol Microbiol 60, 2036-2041.

Baldani, V. L. D., Oliveira, E., Balota, E., Baldani, J. I., Kirchhof, G. \& Döbereiner, J. (1997). Burkholderia brasilensis sp. nov., uma nova espécie de bactéria diazotrófica endofitica. An Acad Bras Cienc 69, 116 (in Portuguese).

Brämer, C. O., Vandamme, P., da Silva, L. F., Gomez, J. G. C. \& Steinbüchel, A. (2001). Burkholderia sacchari sp. nov., a polyhydroxyalkanoate-accumulating bacterium isolated from soil of a sugar-cane plantation in Brazil. Int J Syst Evol Microbiol 51, 1709-1713.

Burris, R. H. (1972). Nitrogen fixation - assay methods and techniques. Methods Enzymol 24, 415-431.

Caballero-Mellado, J., Martínez-Aguilar, L., Paredes-Valdez, G. \& Santos, P. E. (2004). Burkholderia unamae sp. nov., an $\mathrm{N}_{2}$-fixing 
rhizospheric and endophytic species. Int J Syst Evol Microbiol 54, 1165-1172.

Caballero-Mellado, J., Onofre-Lemus, J., Estrada-de Los Santos, P. \& Martínez-Aguilar, L. (2007). The tomato rhizosphere, an environment rich in nitrogen-fixing Burkholderia species with capabilities of interest for agriculture and bioremediation. Appl Environ Microbiol 73, 5308-5319.

Chen, W. M., James, E. K., Coenye, T., Chou, J. H., Barrios, E., de Faria, S. M., Elliott, G. N., Sheu, S. Y., Sprent, J. I. \& Vandamme, P. (2006). Burkholderia mimosarum sp. nov., isolated from root nodules of Mimosa spp. from Taiwan and South America. Int J Syst Evol Microbiol 56, 1847-1851.

Chen, W.-M., de Faria, S. M., James, E. K., Elliott, G. N., Lin, K.-Y., Chou, J.-H., Sheu, S.-Y., Cnockaert, M., Sprent, J. I. \& Vandamme, P. (2007). Burkholderia nodosa sp. nov., isolated from root nodules of the woody Brazilian legumes Mimosa bimucronata and Mimosa scabrella. Int J Syst Evol Microbiol 57, 1055-1059.

Chun, J., Lee, J.-H., Jung, Y., Kim, M., Kim, S., Kim, B. K. \& Lim, Y.-W. (2007). EzTaxon: a web-based tool for the identification of prokaryotes based on $16 \mathrm{~S}$ ribosomal RNA gene sequences. Int J Syst Evol Microbiol 57, 2259-2261.

Coenye, T. \& Vandamme, P. (2003). Diversity and significance of Burkholderia species occupying diverse ecological niches. Environ Microbiol 5, 719-729.

Ezaki, T., Hashimoto, Y., Takeuchi, N., Yamamoto, H., Liu, S. L., Miura, H., Matsui, K. \& Yabuuchi, E. (1988). Simple genetic method to identify viridans group streptococci by colorimetric dot hybridization and fluorometric hybridization in microdilution wells. $J$ Clin Microbiol 26, 1708-1713.

Ezaki, T., Hashimoto, Y. \& Yabuuchi, E. (1989). Fluorometric deoxyribonucleic acid-deoxyribonucleic acid hybridization in microdilution wells as an alternative to membrane filter hybridization in which radioisotopes are used to determine genetic relatedness among bacterial strains. Int J Syst Bacteriol 39, 224-229.

Felsenstein, J. (1981). Evolutionary trees from DNA sequences: a maximum likelihood approach. J Mol Evol 17, 368-376.

Felsenstein, J. (1985). Confidence limits on phylogenies: an approach using the bootstrap. Evolution 39, 783-791.

Felsenstein, J. (2005). PHYLIP (Phylogeny Inference Package) version 3.65. Distributed by the author. Department of Genome Sciences, University of Washington, Seattle, USA.

Hashidoko, Y., Tada, M., Osaki, M. \& Tahara, S. (2002). Soft gel medium solidified with gellan gum for preliminary screening for root-associating, free-living nitrogen-fixing bacteria inhabiting the rhizoplane of plants. Biosci Biotechnol Biochem 66, 2259-2263.

Jukes, T. H. \& Cantor, C. R. (1969). Evolution of protein molecules. In Mammalian Protein Metabolism, vol. 2, pp. 21-132. Edited by H. N. Munro. New York: Academic Press.

Kimoto, K., Aizawa, T., Urai, M., Nguyen, B. V., Suzuki, K., Nakajima, M. \& Sunairi, M. (2010). Acidocella aluminiidurans sp. nov., an aluminium-tolerant bacterium isolated from Panicum repens grown in a highly acidic swamp in actual acid sulfate soil area of Vietnam. Int $J$ Syst Evol Microbiol 60, 764-768.

Kluge, A. G. \& Farris, F. S. (1969). Quantitative phyletics and the evolution of anurans. Syst Zool 18, 1-32.

Martínez-Aguilar, L., Díaz, R., Peña-Cabriales, J. J., Estrada-de Los Santos, P., Dunn, M. F. \& Caballero-Mellado, J. (2008). Multichromosomal genome structure and confirmation of diazotrophy in novel plant-associated Burkholderia species. Appl Environ Microbiol 74, 4574-4579.

Perin, L., Martínez-Aguilar, L., Paredes-Valdez, G., Baldani, J. I., Estrada-de Los Santos, P., Reis, V. M. \& Caballero-Mellado, J.
(2006). Burkholderia silvatlantica sp. nov., a diazotrophic bacterium associated with sugar cane and maize. Int J Syst Evol Microbiol 56, 1931-1937.

Pot, B., Vandamme, P. \& Kersters, K. (1994). Analysis of electrophoretic whole-organism protein fingerprints. In Modern Microbial Methods (Chemical Methods Prokaryotic Systematics Series), pp. 493-521. Edited by M. Goodfellow \& A. G. O’Donnell. Chichester: Wiley.

Reis, V. M., Estrada-de los Santos, P., Tenorio-Salgado, S., Vogel, J., Stoffels, M., Guyon, S., Mavingui, P., Baldani, V. L., Schmid, M. \& other authors (2004). Burkholderia tropica sp. nov., a novel nitrogenfixing, plant-associated bacterium. Int J Syst Evol Microbiol 54, 21552162.

Ryu, E. (1938). On the Gram-differentiation of bacteria by the simplest method. J Jpn Soc Vet Sci 17, 31.

Rzhetsky, A. \& Nei, M. (1992). A simple method for estimating and testing minimum evolution trees. Mol Biol Evol 9, 945-967.

Saitou, N. \& Nei, M. (1987). The neighbor-joining method: a new method for reconstructing phylogenetic trees. Mol Biol Evol 4, 406425.

Sasaki, S., Ishii, R., Hasegawa, I., Tokuyama, T., Hanzawa, K., Sumida, H., Ueda, S., Noguchi, A.,, Matsumoto, R. \& other authors (2008). Development of New Bioremediation Systems of Acid Sulfate Soil for Agriculture and Forestry. Kyoto: Shoukadoh.

Smibert, R. M. \& Krieg, N. R. (1994). Phenotypic characterization. In Methods for General and Molecular Bacteriology, pp. 607-654. Edited by P. Gerhardt, R. G. E. Murray, W. A. Wood \& N. R. Krieg. Washington, DC: American Society for Microbiology.

Stackebrandt, E. \& Goebel, B. (1994). Taxonomic note: a place for DNA-DNA reassociation and $16 \mathrm{~S}$ rRNA sequence analysis in the present species definition in bacteriology. Int J Syst Bacteriol 44, 846849.

Tamaoka, J. \& Komagata, K. (1984). Determination of DNA base composition by reversed-phase high-performance liquid chromatography. FEMS Microbiol Lett 25, 125-128.

Tamura, T. \& Hatano, K. (2001). Phylogenetic analysis of the genus Actinoplanes and transfer of Actinoplanes minutisporangius Ruan et al. 1986 and 'Actinoplanes aurantiacus' to Cryptosporangium minutisporangium comb. nov. and Cryptosporangium aurantiacum sp. nov. Int $J$ Syst Evol Microbiol 51, 2119-2125.

Tamura, T., Nakagaito, Y., Nishii, T., Hasegawa, T., Stackebrandt, E. \& Yokota, A. (1994). A new genus of the order Actinomycetales, Couchioplanes gen. nov., with descriptions of Couchioplanes caeruleus (Horan and Brodsky 1986) comb. nov. and Couchioplanes caeruleus subsp. azureus subsp. nov. Int J Syst Bacteriol 44, 193-203.

Tamura, T., Hayakawa, M. \& Hatano, K. (1999). Sporichthya brevicatena sp. nov. Int J Syst Bacteriol 49, 1779-1784.

Tamura, K., Dudley, J., Nei, M. \& Kumar, S. (2007). MEGA4: molecular evolutionary genetics analysis (MEGA) software version 4.0. Mol Biol Evol 24, 1596-1599.

Thompson, J. D., Gibson, T. J., Plewniak, F., Jeanmougin, F. \& Higgins, D. G. (1997). The CLUSTAL_X windows interface: flexible strategies for multiple sequence alignment aided by quality analysis tools. Nucleic Acids Res 25, 4876-4882.

Valverde, A., Delvasto, P., Peix, A., Velázquez, E., Santa-Regina, I., Ballester, A., Rodríguez-Barrueco, C., García-Balboa, C. \& Igual, J. M. (2006). Burkholderia ferrariae sp. nov., isolated from an iron ore in Brazil. Int J Syst Evol Microbiol 56, 2421-2425.

Vandamme, P., Pot, B., Gillis, M., De Vos, P., Kersters, K. \& Swings, J. (1996). Polyphasic taxonomy, a consensus approach to bacterial systematics. Microbiol Rev 60, 407-438. 
Vandamme, P., Goris, J., Chen, W.-M., De Vos, P. \& Willems, A. (2002). Burkholderia tuberum sp. nov. and Burkholderia phymatum sp. nov., nodulate the roots of tropical legumes. Syst Appl Microbiol 25, 507-512.

Wayne, L. G., Brenner, D. J., Colwell, R. R., Grimont, P. A. D., Kandler, O., Krichevsky, M. I., Moore, L. H., Moore, W. E. C., Murray, R. G. E. \& other authors (1987). Report of the ad hoc committee on reconciliation of approaches to bacterial systematics. Int J Syst Bacteriol 37, 463-464.

Weber, O. B., Baldani, V. L. D., Teixeira, K. R. S., Kirchhof, G., Baldani, J. I. \& Döbereiner, J. (1999). Isolation and characterization of diazotrophic bacteria from banana and pineapple plants. Plant Soil 210, 103-113.

Yabuuchi, E., Kosako, Y., Oyaizu, H., Yano, I., Hotta, H., Hashimoto, Y., Ezaki, T. \& Arakawa, M. (1992). Proposal of Burkholderia gen. nov. and transfer of seven species of the genus Pseudomonas homology group II to the new genus, with the type species Burkholderia cepacia (Palleroni and Holmes 1981) comb. nov. Microbiol Immunol 36, 12511275.

Yamada, Y., Takinami-Nakamura, H., Tahara, Y., Oyaizu, H. \& Komagata, K. (1982). The ubiquinone systems in the strains of Pseudomonas species. J Gen Appl Microbiol 28, 7-12.

Yang, H. C., Im, W. T., Kim, K. K., An, D. S. \& Lee, S. T. (2006). Burkholderia terrae sp. nov., isolated from a forest soil. Int J Syst Evol Microbiol 56, 453-457.

Zhang, H., Hanada, S., Shigematsu, T., Shibuya, K., Kamagata, Y., Kanagawa, T. \& Kurane, R. (2000). Burkholderia kururiensis sp. nov., a trichloroethylene (TCE)-degrading bacterium isolated from an aquifer polluted with TCE. Int J Syst Evol Microbiol 50, 743-749. 